\title{
Prevalence of diabetes in Brazil over time: a systematic review with meta-analysis
}

\author{
Gabriela H. Telo ${ }^{1 *}$, Felipe Vogt Cureau², Martina S. de Souza'1, Thais S. Andrade1', Fabiana Copês 1,3 \\ and Beatriz D. Schaan 1,2,4
}

\begin{abstract}
Diabetes is one of the most important epidemic diseases of this century and the number of people with diabetes has more than doubled over the past three decades. Our aim was to estimate the prevalence of diabetes in the adult Brazilian population and analyze the trends for the last three decades through a systematic review with meta-analysis. This review included observational studies published between 1980 and 2015, which were independently identified by two reviewers in five databases. Random effect models were used to estimate the prevalence and trends of diabetes. In total, 50 articles were included in this review. Three different patterns for diabetes diagnosis were identified: self-report (36 studies), fasting glucose (7 studies), and complex diagnosis (fasting glucose, oral glucose tolerance test, and self-report; 7 studies). The prevalence of diabetes was $5.6 \%\left(95 \% \mathrm{Cl}\right.$ 5.0-6.3; $\mathrm{I}^{2}=100 \%$ ) by self-report, $6.6 \%$ $\left(95 \% \mathrm{Cl} 4.8-8.9 ; \mathrm{I}^{2}=94 \%\right)$ by fasting glucose, and $11.9 \%\left(95 \% \mathrm{Cl} 7.7-17.8 \mathrm{I}^{2}=100 \%\right)$ by complex diagnosis. In trend analyses, we observed an increase in the prevalence of diabetes over time. The biggest increase was detected in studies using complex diagnosis: $7.4 \%$ (95 \% Cl 7.1-7.7) in the 1980s to $15.7 \%$ (95 \% Cl 9.8-24.3) in the 2010 s. In conclusion, despite high heterogeneity, this study observed a high prevalence of diabetes in Brazilian adults over time and with a progressive increase in the last 35 years.
\end{abstract}

Keywords: Type 2 diabetes, Prevalence, Brazil

\section{Background}

Diabetes is one of the most important epidemic diseases of this century. The global prevalence of type 2 diabetes is increasing worldwide as a result of population ageing [1], rising rates of overweight and obesity in adults as well as youth [2], and reduced risk of mortality among patients with diabetes [3]. The number of people with diabetes has more than doubled over the past three decades in nearly every nation of the world [4]. In 2014, the global prevalence of diabetes was estimated to be $9 \%$ among adults older than 18 years old [5]. It has been projected that there will be 366 million adults with diabetes in 2030 [6]

\footnotetext{
*Correspondence: gabrielatelo@yahoo.com.br

${ }^{1}$ Internal Medicine Department, Medical School, Universidade Federal do Rio Grande do Sul, Rua Ramiro Barcelos, 2350, Porto Alegre CEP 90035-903, Brazil

Full list of author information is available at the end of the article
}

and, despite recent declines in mortality, diabetes will be the seventh leading cause of death in 15 years [7], making it one of the most important public health challenges to all nations [8].

The major burden of diabetes is now taking place in developing rather than in developed countries, and $80 \%$ of patients with diabetes live in less developed areas [8]. All the Latin American countries have undergone rapid demographic, epidemiological and nutritional transitions [9], which strongly contributed to the increasing prevalence of diabetes. Brazil is one of the most important examples of this alarming problem in less developed societies with the fourth largest number of people with type 2 diabetes [10]. In the South and Central America region, $8.0-11.3 \%$ of the adult population have diabetes. Of these, $39.0 \%$ are undiagnosed. Moreover, Brazil has the highest number of people with diabetes in the region. In 2015, in Latin America, almost 250,000 adults died as 
a result of diabetes, of which half of the deaths occurred in Brazil [11]. The International Diabetes Federation estimated the prevalence of diabetes in Brazil to be $10.3 \%$ in 2012 [12], which represents a gradual increase over the past three decades.

This rising diabetes prevalence has translated into a $60 \%$ increase in the attributable risk ratio for cardiovascular diseases associated with diabetes [13]. However, there is a lack of nationwide prevalence data over time in most emerging countries. In Brazil, although several cross-sectional analyses have been conducted to identify the prevalence of diabetes [9], no strong and consistent data is available to evaluate the trends over time. In this study, based on the hypothesis of increasing diabetes prevalence over decades and potential regional differences, we sought to investigate existing data sources on the prevalence of diabetes in Brazil and estimate the prevalence trends of diabetes for the last three decades in the adult Brazilian population through a systematic review with meta-analysis of observational studies.

\section{Methods}

\section{Search strategy}

A comprehensive literature search was conducted to identify articles containing information on diabetes prevalence in Brazil. Two reviewers independently searched in five different databases (PubMed, Cochrane Library, EMBASE, LILACS and SciELO). Search strategies were tested to find the appropriate medical subject heading terms for "Diabetes Mellitus", "Brazil" and its regions, and "Prevalence". The complete PubMed literature search strategy is described in the Additional file 1: Table S1. No language or age restrictions were applied. A manual search of the references of review articles, key publications, and abstracts from the two past years of the main national related meetings was also performed. All potentially eligible studies were considered for review. Duplicate data were excluded. The software EndNote version X6 (Thomson Reuters, New York, NY) was used for references selection management.

\section{Study selection}

Additional file 2: Figure S1 shows the flow diagram of the studies included in the meta-analysis. Two independent and previously trained investigators performed the first titles and abstracts screening. All the selected studies were retrieved for full-text evaluation. We included all publications providing information on type 2 diabetes and our aimed end-point: prevalence, based on population-based cross-sectional and baseline of cohort studies among participants aged 18 years or older published between January 1980 and December 2015. Studies in which the sampling was not random or included less than
300 persons were excluded. Studies that assessed only specific subgroups not representative of its geographical strata were considered ineligible. Studies that included women or men only were considered eligible and were included only for analyses by gender. A third investigator solved disagreements between reviewers.

\section{Data extraction and assessment of study quality}

Two reviewers separately evaluated the selected studies for data capture. The data were entered in a pretested Microsoft Office Excel ${ }^{\mathrm{TM}}$ spreadsheet based on the Strengthening in Epidemiology Statement (STROBE) checklist [14, 15]. The absolute rather than relative value of each variable was obtained. Any discordance between the data extracted was discussed until consensus was reached.

All studies were addressed for their capability to appropriately respond to our research question, as well as for selection, measurement, and analysis biases. Selection biases were defined by $20 \%$ or more of refuses to participate in the study and by studies that used telephone calls as the only method for patient selection and interviews. Measurement bias was characterized based on diabetes diagnosis criteria: self-reported or measured. Analysis bias was defined as when a study did not consider the design effect to estimate the diabetes prevalence. Data regarding how the study handled missing data were also obtained. Sensitivity analyses were performed as preestablished to deal with potential study biases.

\section{Statistical analysis}

Random effect models were used to calculate all point estimates and their $95 \%$ confidence interval ( $95 \% \mathrm{CI})$, as well as to estimate the prevalence of diabetes for the general population. Sensitivity analyses were performed by sex, decades, macro-region, and diagnostic criteria. Logit transformation was used to handle distribution asymmetry related to different prevalence measures. Continuity correction was used for adjustment when a discrete distribution was approximated by a continuous distribution. Prevalence was weighted by the inverse variance of logit. Pooled values were then converted to prevalence. Chi square was used to determine differences in prevalence rates among different decades. The Cochran Chi square and $I^{2}$ test were used to evaluate statistical heterogeneity and consistency among the studies, and a value of $p=0.10$ was used for significance.

Statistical analyses were performed using Stata version 12.1 (StataCorp LP, College Station, TX). MetaXL (EpiGear International, Sunrise Beach, Australia), an Excel comprehensive program for meta-analysis was used to build forest plots. Before start any study procedure, this study was registered [16] at PROSPERO, an international database of prospectively registered systematic reviews in 
health and social care, under the registration number of CRD42014010602.

\section{Results}

Synthesis of data

The search retrieved 2522 articles from January 1980 to December 2015, of which 496 were duplicates and were excluded. Additional 1909 articles were removed based on title and abstracts; 117 full-text articles were assessed for eligibility, of which 40 met all the inclusion criteria. Manual search retrieved other ten articles, totalizing 50 studies $(1,393,637$ individuals) that were included in the final analyses. The flowchart of studies selection is presented in Fig. 1. Three different patterns for diabetes diagnosis were identified: self-report, fasting glucose, and complex diagnosis [e.g. fasting glucose + oral glucose tolerance test (OGTT) + self-report]. The characteristics of the included studies by diagnosis criteria and method of assessment are described in Table 1.

A meta-analysis was conducted according to the diagnosis pattern. Prevalence rates are presented in Figs. 1 (self-reported), 2 (fasting glucose) and 3 (complex diagnosis), respectively. The prevalence of diabetes was $5.6 \%$ (95 \% CI 5.0-6.3) by self-report, $6.6 \%$ (95 \% CI 4.8-8.9) by fasting glucose, and $11.9 \%$ ( $95 \%$ CI 7.7-17.8) by complex diagnosis. In trend analyses, we observed an increase in the prevalence of diabetes in studies using a selfreported diagnosis [3.2 \% (95\% CI 2.6-4.1) in the 1990s, $5.7 \%$ (95 \% CI 5.1-6.4) in the 2000s, and $6.9 \%$ (95\% CI 6.2-7.6) in the 2010s] and studies using a complex diagnosis [7.4 \% (95 \% CI 7.1-7.7) in the 1980s, $12.1 \%$ (95\% CI 10.5-13.8) in the $1990 \mathrm{~s}, 14.5 \%$ (95\% CI 13.1-16.0) in the 2000s, and $15.7 \%$ (95 \% CI 9.8-24.3) in the 2010s]. Only one study evaluated the prevalence of diabetes by fasting glucose in the 1990 s (10.3\%; $95 \%$ CI 9.1-11.6); the other six studies were conducted in the 2000s $(6.0 \%$; $95 \%$ CI 4.2-8.6). High statistical heterogeneity was identified in all analyses (data presented in Figs. 1, 2, 3).

In comparison to males, a female preponderance with regard to prevalence of diabetes was seen in this study in all decades and diagnosis criteria. Trends for the last three decades of diabetes prevalence by sex and decades are presented in Additional file 3: Figure S2 (selfreported), Additional file 4: Figure S3 (fasting glucose) and Additional file 5: Figure S4 (complex diagnosis). Prevalence rates of diabetes and their $95 \%$ CI by sex, age group, regions, and adjustment to the design effect are presented in Table 2 . The data presented in this table shows that the prevalence of diabetes was similar among the five different Brazilian macro-regions, and higher in older people. When analyses were adjusted to the design effect, the prevalence of diabetes was lower than the prevalence observed in not adjusted analyses.

\section{Quality of studies}

Additional file 6: Figure S5 summarizes data regarding quality of studies. Most studies were based on crosssectional design (49 studies, $96 \%$ ). Three different patterns of diabetes diagnosis were identified and included in this analysis: self-report (36 studies, $72 \%$ ), fasting glucose (7 studies, $14 \%$ ), and complex diagnosis (7 studies, $14 \%)$. Sample sizes varied substantially with a mean of 27.521 people. The mostly used design was cluster sampling (45 studies, $90 \%$ ), and sample size calculation was well described in 42 studies (84\%). Most studies were developed only in or including data from Southeast and Southern Brazil (35 studies, $70 \%$ and 30 studies, $60 \%$, respectively), and 25 studies (50\%) included data from rural areas. Most studies did not have selection bias with potential to compromise internal validity (32 studies, $64 \%$ ), as well as analysis bias (43 studies, $86 \%$ ); however, only ten studies $(20 \%)$ appropriately described handling of missing data.

\section{Discussion}

Decades ago, the global epidemic of diabetes was predicted by epidemiologists who observed large and rapid increases in the prevalence of type 2 diabetes related to Western lifestyle [65]. Over time, the burden of diabetes has taken place in developing rather than in developed countries [66]. In the present systematic review with meta-analysis of cross-sectional and baseline of cohort studies, which included more than one million individuals, it was possible to estimate the prevalence of diabetes in Brazil by decades, sex, macro-region, diagnosis criteria, and methods of assessment. Studies based on a complex diagnosis showed a high prevalence of diabetes in Brazilian adults (11.9\%), with a progressive increase in the last 35 years. This trend was also apparently observed in studies based on self-reported diagnosis.

The prevalence of diabetes in Brazil by self-reported method was lower than the other methods used in this study (complex diagnosis and fasting glucose); however, it was observed a progressive increase in prevalence for all detection methods in the last 35 years. This finding may be, in part, due to greater access to diagnostic testing [67], as well as the recognition of different diagnostic criteria tests for diabetes diagnosis [68]. A same telephone survey platform, which yearly evaluates diabetes prevalence in Brazil, identified an increase in the overall prevalence of diabetes from 6.3 to $8 \%$ in just 5 years, a $21 \%$ jump $[46,50]$.

Moreover, the diagnosis criteria for diabetes based on OGTT and fasting glucose became broader over time, which may differentially identify people without previous diagnosis as having diabetes [69]. It may explain, to some extent, the progressive increase in 


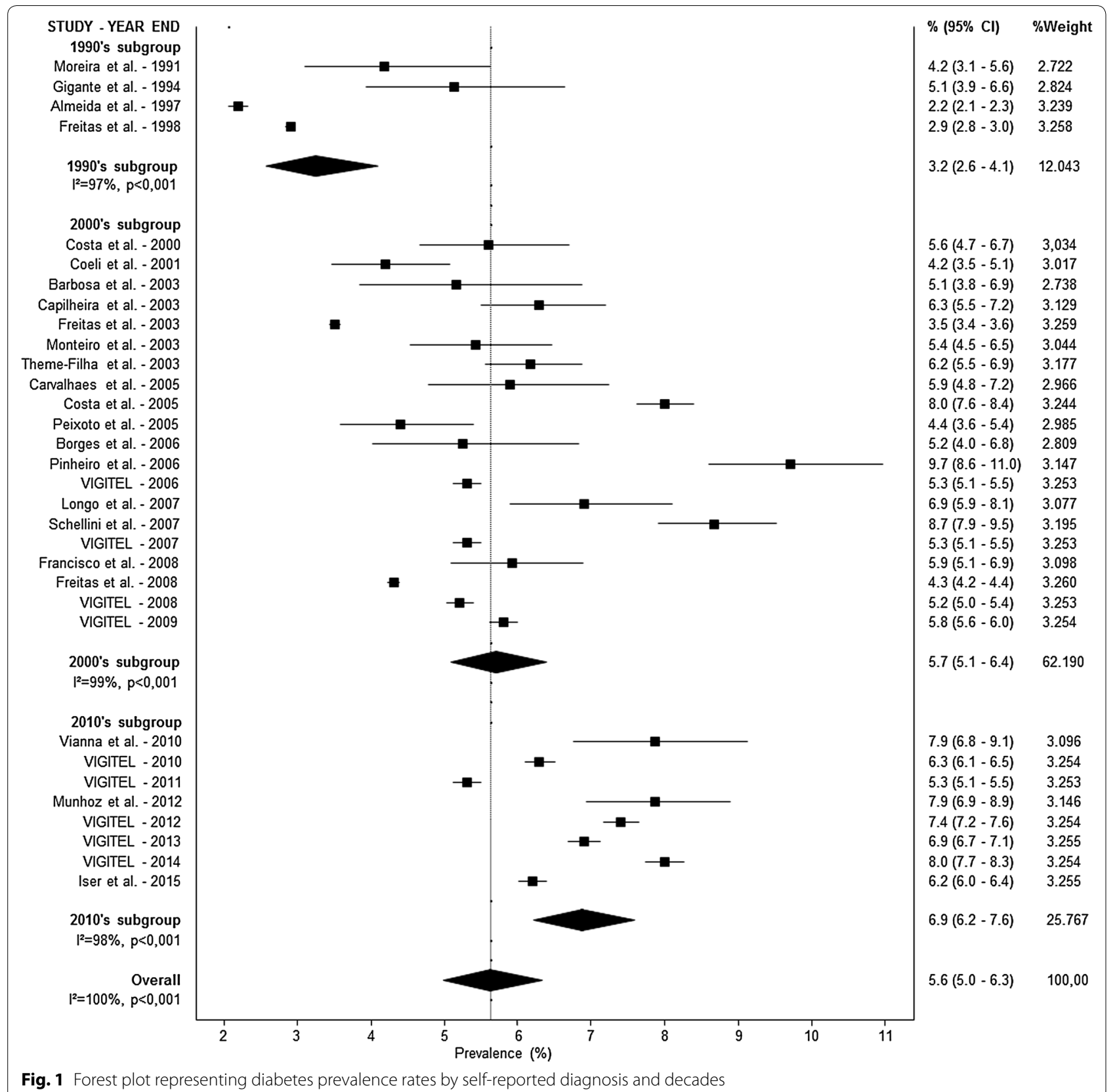

diabetes prevalence, as different biomarkers and definitions for diabetes may provide different estimates of population prevalence. Different biomarkers have been used to define diabetes, including fasting glucose, OGTT, and, more recently, HbA1c [69]. In this metaanalysis, only one study included HbA1c as diagnosis criteria for diabetes [40]. Results showed that approximately $10 \%$ of cases were diagnosed only by HbA1c method, which can help to explain the high prevalence found. In this study, the prevalence of diabetes remained similar after adjustment by gender, age, skin color, weight status, and education level [40]. Population-based health surveys in different countries and at different times have also used different biomarkers and criteria for diabetes diagnosis, which define diabetes differently. This variety of biomarkers and definitions creates a challenge in consistently analyzing diabetes prevalence over time. In a large international pooled analysis of population-based examination surveys, it was found that the use of these different biomarkers 


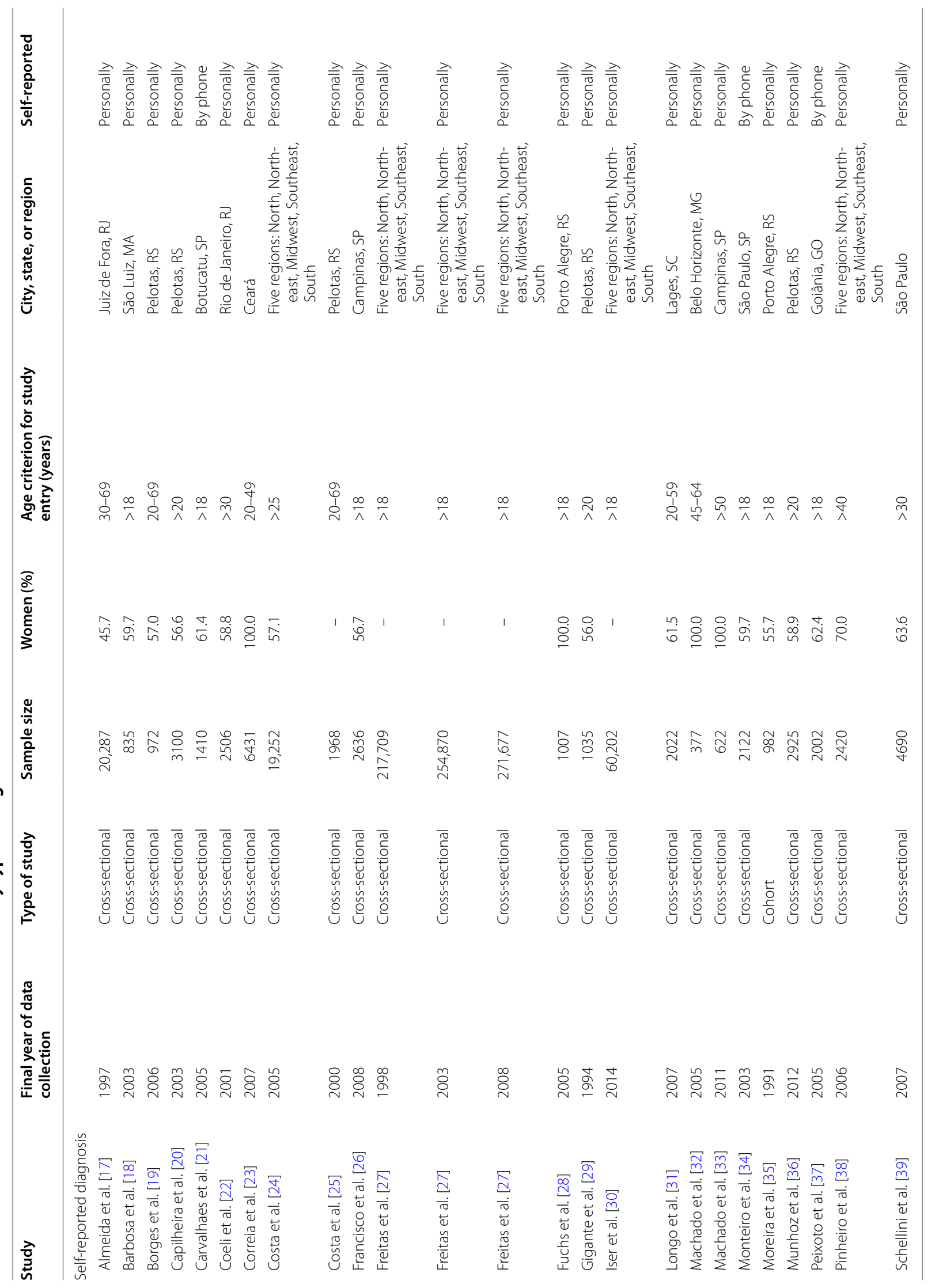




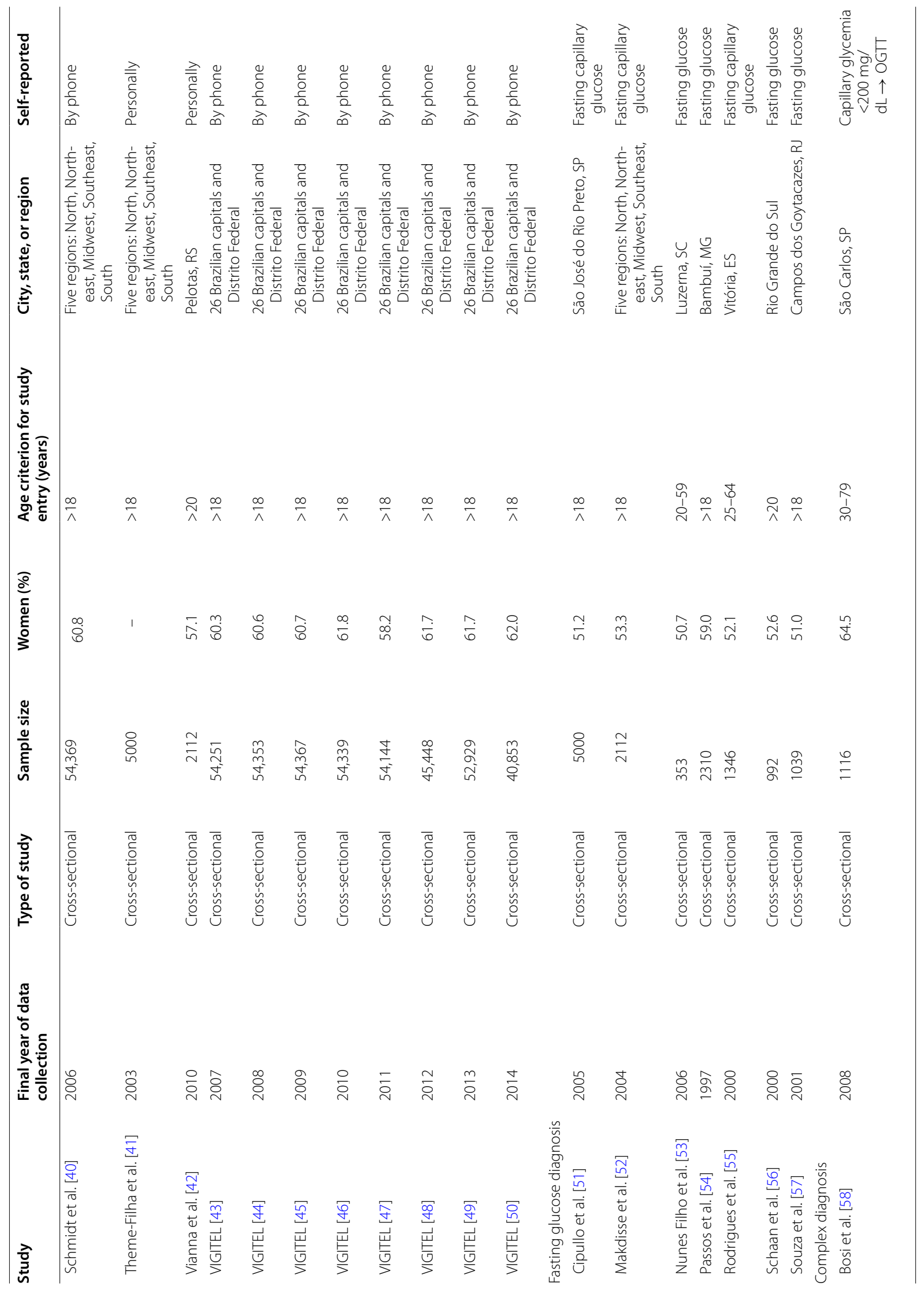




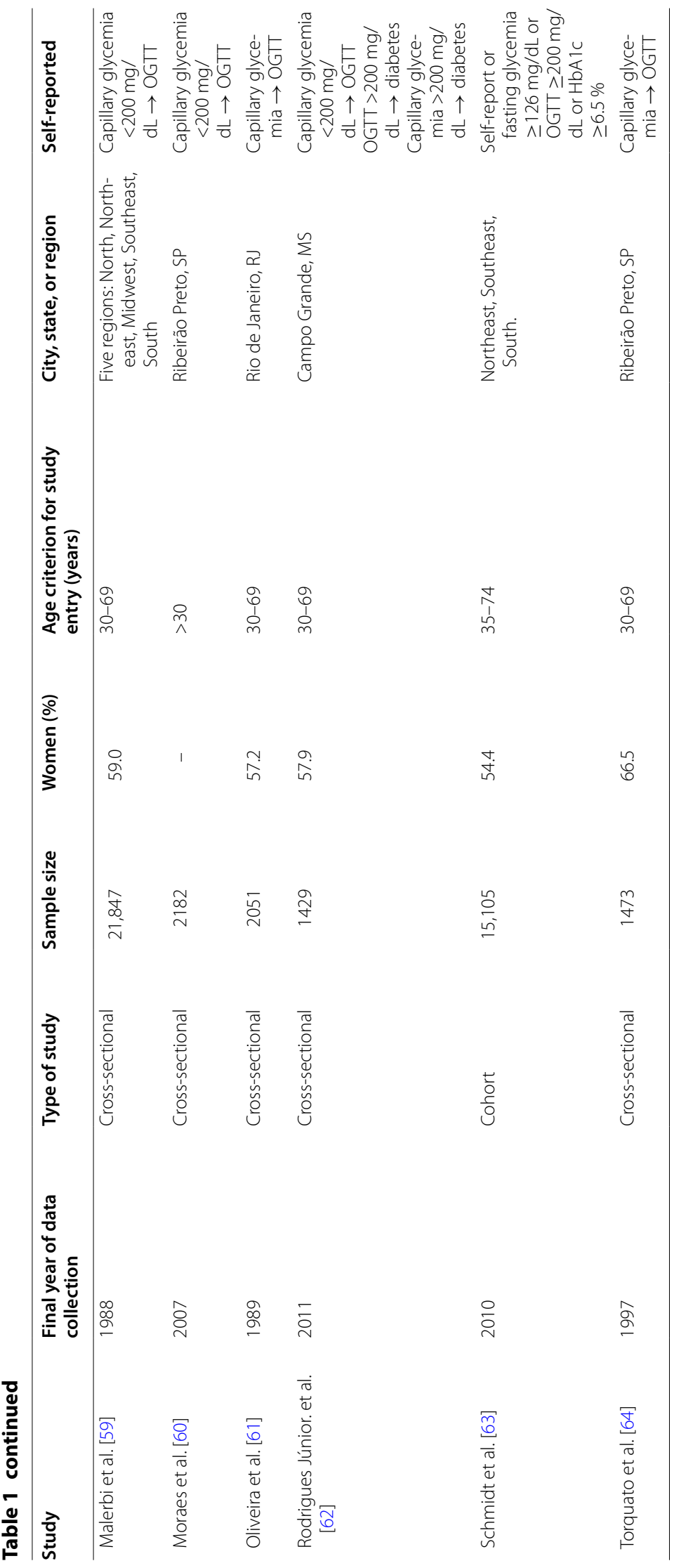




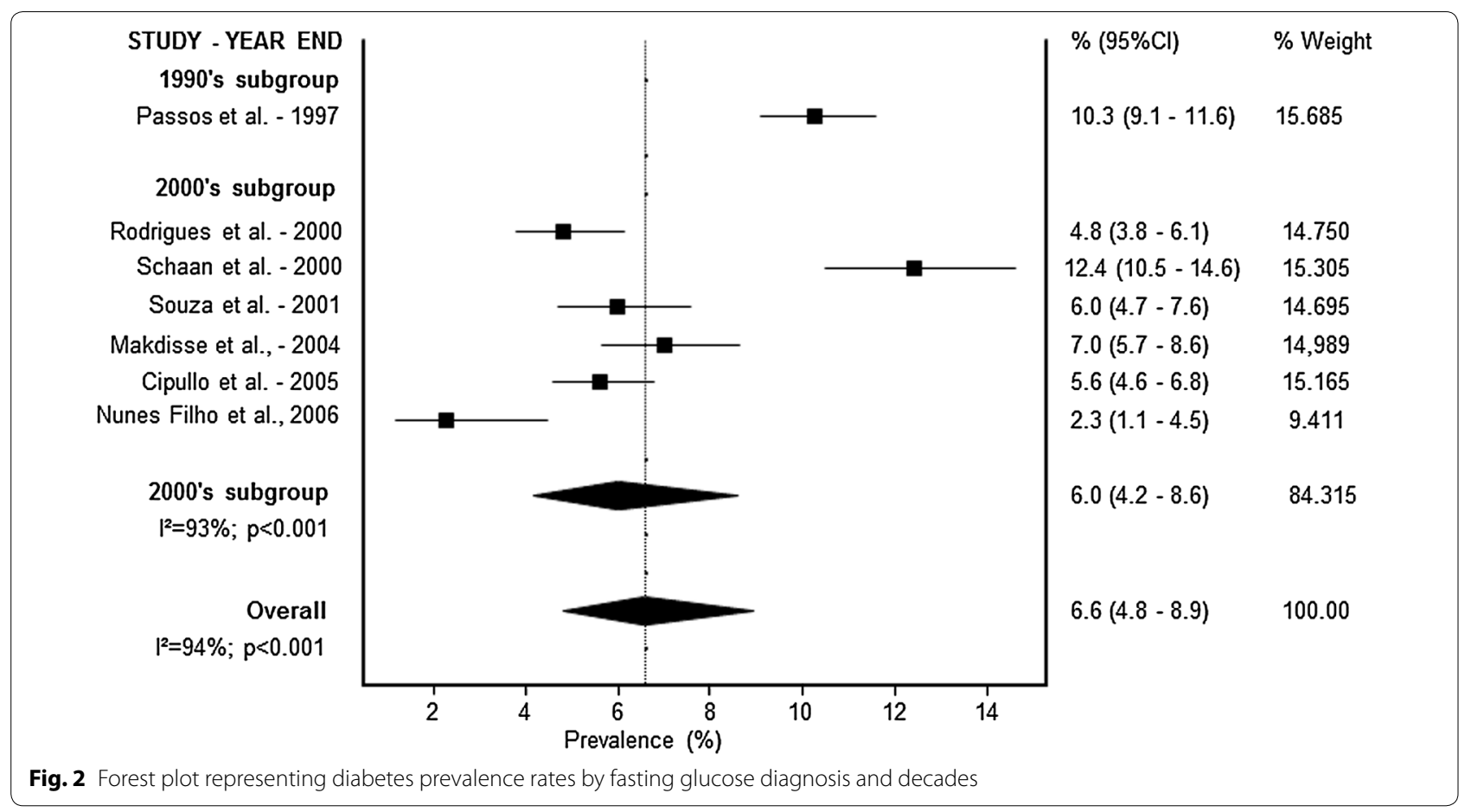

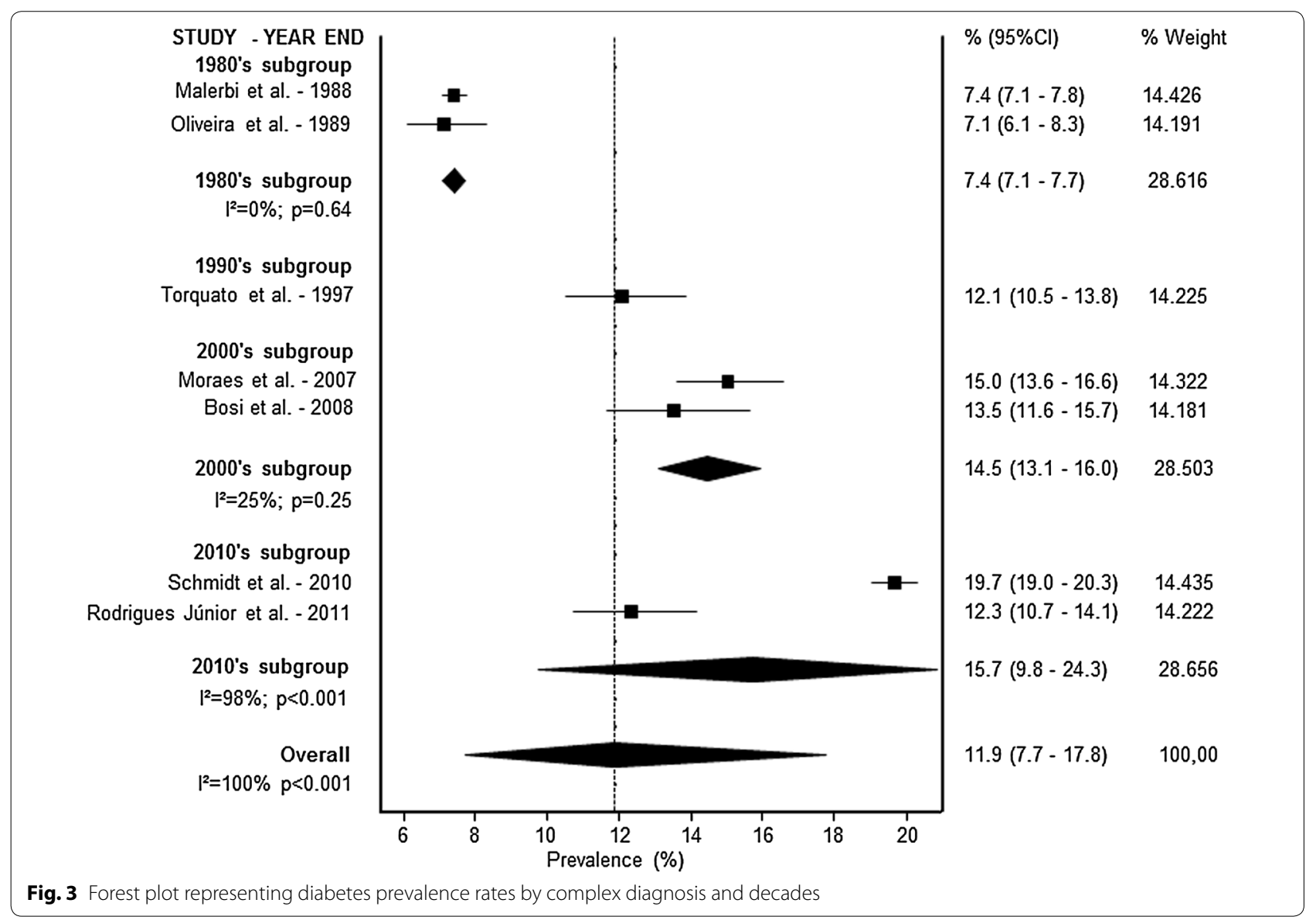


Table 2 Subgroup meta-analysis of diabetes prevalence in Brazilian adults by diagnosis type and sex

\begin{tabular}{|c|c|c|c|c|c|c|c|c|c|}
\hline \multirow[t]{2}{*}{ Variables } & \multicolumn{3}{|c|}{ Overall } & \multicolumn{3}{|c|}{ Female } & \multicolumn{3}{|c|}{ Male } \\
\hline & $\mathrm{N}$ & $\%(95 \% \mathrm{Cl})$ & $I^{2} \%$ & $\mathbf{N}$ & $\%(95 \% \mathrm{Cl})$ & $I^{2} \%$ & $\mathrm{~N}$ & $\%(95 \% \mathrm{Cl})$ & $I^{2} \%$ \\
\hline \multicolumn{10}{|l|}{ Self-reported } \\
\hline \multicolumn{10}{|l|}{ Age group (years) } \\
\hline $20-69$ & 5 & $5.1(2.6-9.8)$ & 99 & 4 & $5.1(3.3-7.8)$ & 98 & 2 & $2.7(0.7-9.1)$ & 99 \\
\hline$>18$ & 23 & $5.5(4.8-6.3)$ & 100 & 21 & $6.1(5.5-6.9)$ & 99 & 20 & $5.0(4.2-6.0)$ & 99 \\
\hline$>30$ & 3 & $7.2(4.8-10.6)$ & 97 & 4 & $9.0(4.8-16.3)$ & 98 & 3 & $6.0(3.7-9.7)$ & 92 \\
\hline \multicolumn{10}{|l|}{ Region } \\
\hline South & 8 & $6.2(5.4-7.1)$ & 78 & 5 & $7.3(6.9-7.7)$ & 0 & 3 & $5.5(4.8-6.4)$ & 0 \\
\hline Southeast & 6 & $5.0(2.7-8.9)$ & 99 & 7 & $7.4(4.7-11.6)$ & 97 & 6 & $3.9(1.9-8.0)$ & 99 \\
\hline Midwest & 1 & $4.4(3.6-5.4)$ & - & 1 & $4.4(3.4-5.7)$ & - & 1 & $4.3(3.1-6.0)$ & - \\
\hline Northeast & 1 & $5.1(3.8-6.9)$ & - & 1 & $4.7(4.2-5.3)$ & - & - & - & - \\
\hline Multiples/national & 15 & $5.7(4.9-6.8)$ & 100 & 15 & $5.8(5.0-6.7)$ & 100 & 15 & $5.2(4.2-6.3)$ & 100 \\
\hline \multicolumn{10}{|l|}{ Adjusted $^{\mathrm{a}}$} \\
\hline Yes & 15 & $5.3(4.5-6.2)$ & 99 & 16 & $5.7(4.9-6.5)$ & 99 & 16 & $4.5(3.7-5.4)$ & 99 \\
\hline No & 16 & $5.9(4.4-7.9)$ & 99 & 13 & $7.4(5.4-9.9)$ & 99 & 9 & $5.6(3.2-9.5)$ & 99 \\
\hline Overall & 31 & $5.7(5.1-6.4)$ & 100 & 29 & $6.3(5.7-7.1)$ & 100 & 25 & $4.9(4.1-5.7)$ & 99 \\
\hline \multicolumn{10}{|l|}{ Fasting glucose } \\
\hline \multicolumn{10}{|l|}{ Age group (years) } \\
\hline $20-69$ & 2 & $3.6(1.7-7.3)$ & 76 & 2 & $2.0(0.3-12.9)$ & 76 & 2 & $5.1(3.8-6.8)$ & 0 \\
\hline$>18$ & 5 & $6.0(4.7-7.6)$ & 93 & 3 & $9.5(6.5-13.7)$ & 8.7 & 3 & $9.0(6.3-12.7)$ & 83 \\
\hline \multicolumn{10}{|l|}{ Region } \\
\hline South & 2 & $5.6(1.0-25.8)$ & 96 & 2 & $3.2(0.1-42.9)$ & 90 & 2 & $7.6(2.4-21.4)$ & 89 \\
\hline Southeast & 4 & $6.4(4.3-9.5)$ & 94 & 3 & $6.7(3.4-12.5)$ & 94 & 3 & $6.8(4.9-9.3)$ & 73 \\
\hline Multiples/national & 1 & $7.0(5.7-8.6)$ & - & - & - & - & - & - & - \\
\hline \multicolumn{10}{|l|}{ Adjusted $^{\mathrm{a}}$} \\
\hline Yes & 1 & $6.0(4.7-7.6)$ & - & 1 & $5.7(4.0-8.0)$ & - & 1 & $6.3(4.5-8.8)$ & - \\
\hline No & 6 & $6.7(4.7-9.4)$ & 94 & 4 & $7.2(4.1-12.3)$ & 92 & 4 & $7.5(4.9-11.4)$ & 86 \\
\hline Overall & 7 & $6.6(4.8-8.9)$ & 94 & 5 & $6.8(4.2-11.0)$ & 92 & 5 & $7.3(5.1-10.3)$ & 84 \\
\hline \multicolumn{10}{|l|}{ Complex diagnosis } \\
\hline \multicolumn{10}{|l|}{ Age group (years) } \\
\hline $30-69$ & 4 & $9.4(7.0-12.6)$ & 96 & & $9.6(7.2-12.5)$ & 93 & 4 & $9.0(6.4-12.4)$ & 92 \\
\hline Others $^{b}$ & 3 & $16.0(12.5-20.4)$ & 96 & & $16.3(15.7-17.1)$ & 0 & & $16.6(11.1-24.1)$ & 95 \\
\hline \multicolumn{10}{|l|}{ Region } \\
\hline Southeast & 4 & $11.6(8.4-15.7)$ & 95 & 4 & $12.8(8.9-17.2)$ & 94 & 4 & $10.7(6.7-16.7)$ & 93 \\
\hline Midwest & 1 & $12.3(10.7-14.1)$ & - & 1 & $12.1(10.0-14.4)$ & - & 1 & $12.6(10.2-15.5)$ & - \\
\hline Multiples/national & 2 & $12.3(4.5-29.5)$ & 100 & 2 & $11.4(3.4-21.2)$ & 100 & 2 & $13.3(4.1-35.8)$ & 100 \\
\hline \multicolumn{10}{|l|}{ Adjusted $^{\mathrm{a}}$} \\
\hline Yes & 6 & $11.5(6.4-17.7)$ & 100 & 6 & $11.5(7.5-16.2)$ & 99 & 6 & $11.0(5.9-19.5)$ & 99 \\
\hline No & 1 & $15.0(13.6-16.6)$ & - & 1 & $17.0(15.2-18.9)$ & - & 1 & $16.6(13.9-19.6)$ & - \\
\hline Overall & 7 & $11.9(7.7-17.8)$ & 100 & 7 & $12.2(8.4-16.6)$ & 99 & 7 & $11.7(6.8-19.3)$ & 99 \\
\hline
\end{tabular}

Complex diagnosis: OGTT + fasting glucose + self-reported, e.g

a Adjustment to the design effect

b Studies (age): Bosi et al. [58] (30-79); Moraes et al. [60] (>30) and Schmidt et al. [63] (35-74)

and definitions can lead to different estimates of population prevalence of diabetes, with the highest prevalence observed when diabetes was defined based on fasting glucose or OGTT [69].
Although changing definitions could result in variations in diabetes prevalence over time, it doesn't underlie the global increase in diabetes. As obesity is the most important risk factor for type 2 diabetes, its observed 
increase also influences the current trend in diabetes prevalence. Some studies suggest that more than $80 \%$ of cases of type 2 diabetes can be attributed to obesity, which may also account for many diabetes-related deaths $[70,71]$. The increases in the prevalence of type 2 diabetes, especially in older adults, may also reflect the reduction in major complications and mortality related to diabetes. Between 1988 and 2010, the largest increase in diabetes prevalence in the United States was observed in older adults ( $\geq 65$ years), and only in this age group this increase remained significant after adjustment for body mass index or waist circumference [72]. Furthermore, the incidence of diabetes has been stable in the last years [73]. At the same time, the rates of the major diabetesrelated complications, especially acute myocardial infarction, have declined [74]. In Brazil, the mortality related to diabetes decreased from 1996 to 2011, likely due to better and earlier treatment of the disease, given that the prevalence of diabetes continues to increase. This reduction was approximately twice larger in women (30 vs. $14 \%$ ) over 15 years, suggesting a possible role in the higher prevalence observed for this gender [3]. Possible reasons for the declines in mortality in Brazil over this period include the expanded public health system, especially in terms of primary care, with national programs focused on diabetes $[75,76]$, organization of emergency care facilities, and hot line systems for diabetes support [75].

In this study, we identified a pronounced female preponderance in diabetes prevalence in all decades, using different diagnosis criteria and methods of assessment. This finding is consistent with those observed in other studies, in which sex-related differences in genetics and lifestyle may lead to differences in the risk of developing diabetes and, in consequence, differences in the prevalence of this condition by sex [77]. In Brazil, a comprehensive literature review summarized the prevalence of diabetes through nine studies [9]. In this study, women were more likely than men to report having diabetes. Although this could be easily explained by the fact that higher incidence of diabetes is related to more frequently reported prevalence of diabetes, this finding may also reflect higher use of medical care by women and therefore increased likelihood of being diagnosed. However, this is not a consensus in the literature. Although previous studies in Brazil have found similar results [63], according to the Centers for Disease Control and Prevention, from 1980 to 1998, the age-adjusted diabetes prevalence by sex was similar in the United States, and, from 1999 on, the rate for males began to increase at a faster rate than that for females [78]. More studies controlling for lifestyle differences may help to better understand these findings.

The present study has some limitations. First, the lack of adjustment of some studies for design effect may compromise accuracy of estimate confidence intervals. Moreover, the different assessment methods for diabetes, changes in diagnosis criteria over time, and high heterogeneity found among the studies limit the interpretation of our results. Also, the poor coverage of the evidence base in many Brazilian regions restricts evaluation for obtaining the national diabetes prevalence over time. Our projections for diabetes prevalence trends for the last three decades are relied on demographic statistics, which might not be accurate for many regions and populations. As a result, our findings should not be considered an appropriate equivalent of a nationwide prevalence study. Also, specific therapies and better social and medical care may reduce direct and indirectly associated mortality and increase prevalence. Further studies in all five Brazilian macro-regions should be required to take into account potential racial, cultural, and socioeconomic diversity of this nation as a whole.

In conclusion, despite the high heterogeneity, this systematic review with meta-analysis showed a high prevalence of diabetes in Brazilian adults over time, with a progressive increase in the last 35 years. These findings may be, in part, associated with improvement in access to health services in the same period. Nevertheless, this study has important epidemiological implications. Our findings reinforce the significant rise in the prevalence of diabetes, which may result in heavy health burden associated to this disorder and its related complications. Based on our results, further studies are necessary to better understand the factors associated to the increasing diabetes prevalence in Brazil, which may help to shape future prevention programs.

\section{Additional files}

Additional file 1: Table S1. Literature search strategy used for the pubmed database.

Additional file 2: Figure S1. Flow diagram: identification and selection of articles included in the meta-analysis.

Additional file 3: Figure S2. Forest plot representing diabetes prevalence rates by self-report and decades in (A) women and (B) men.

Additional file 4: Figure S3. Forest plot representing diabetes prevalence rates by fasting glucose and decades in (A) women and (B) men.

Additional file 5: Figure S4. Forest plot representing diabetes prevalence rates by complex diagnosis and decades in (A) women and (B) men.

Additional file 6: Figure S5. Quality of studies characteristics.

\section{Authors' contributions}

Conceived and designed the study: GHT, FVC and BDS. Preformed the experiments: MSS, FVC and TSA. Analyzed the data: FCV, GHT and BDS. Wrote the manuscript: GHT and FVC. Edited and reviewed the manuscript: BDS. Reviewed the manuscript: MSS, FC, and TSA. All authors have approved the final version of this manuscript. All authors read and approved the final manuscript. 


\begin{abstract}
Author details
${ }^{1}$ Internal Medicine Department, Medical School, Universidade Federal do Rio Grande do Sul, Rua Ramiro Barcelos, 2350, Porto Alegre CEP 90035-903, Brazil.

2 Postgraduate Program in Endocrinology, Universidade Federal do Rio Grande do Sul, Porto Alegre, Brazil. ${ }^{3}$ Departament of Nutrition, Universidade Federal do Pampa, Campus Itaqui, Brazil. ${ }^{4}$ Endocrine Division, Hospital de Clínicas de Porto Alegre, Porto Alegre, Brazil.
\end{abstract}

\section{Acknowledgements}

B.D.S. was recipient of educational scholarship from Conselho Nacional de Desenvolvimento Científico e Tecnológico (CNPq, PQ). FVC is supported by Coordenação de Aperfeiçoamento de Pessoal de Nível Superior with a Ph.D. scholarship (process: BEX 9556/14-1). The funder did not have any participation in the study design, data collection, data analysis, manuscript preparation, or publication decisions.

\section{Competing interests}

The authors declare that they have no competing interests.

Received: 20 May 2016 Accepted: 29 August 2016

Published online: 07 September 2016

\section{References}

1. Zimmet P, Alberti KG, Shaw J. Global and societal implications of the diabetes epidemic. Nature. 2001;414(6865):782-7.

2. Hu FB, Manson JE, Stampfer MJ, Colditz G, Liu S, Solomon CG, Willett WC. Diet, lifestyle, and the risk of type 2 diabetes mellitus in women. $\mathrm{N}$ Engl J Med. 2001;345(11):790-7.

3. Schmidt MI, Duncan BB, Ishitani L, da Conceicao Franco G, de Abreu DM, Lana GC, Franca E. Trends in mortality due to diabetes in Brazil, 1996-2011. Diabetol Metab Syndr. 2015;7:109.

4. Danaei G, Finucane MM, Lu Y, Singh GM, Cowan MJ, Paciorek CJ, Lin JK, Farzadfar F, Khang $\mathrm{YH}$, Stevens GA, et al. National, regional, and global trends in fasting plasma glucose and diabetes prevalence since 1980: systematic analysis of health examination surveys and epidemiological studies with 370 country-years and 2.7 million participants. Lancet. 2011;378(9785):31-40

5. World Health Organization. Global status report on noncommunicable diseases 2014. Geneva: World Health Organization; 2012.

6. Wild S, Roglic G, Green A, Sicree R, King H. Global prevalence of diabetes: estimates for the year 2000 and projections for 2030. Diabetes Care. 2004;27(5):1047-53.

7. Mathers CD, Loncar D. Projections of global mortality and burden of disease from 2002 to 2030. PLoS Med. 2006:3(11):e442.

8. Chen L, Magliano DJ, Zimmet PZ. The worldwide epidemiology of type 2 diabetes mellitus - present and future perspectives. Nat Rev Endocrinol. 2012;8(4):228-36

9. Bertoldi AD, Kanavos P, Franca GV, Carraro A, Tejada CA, Hallal PC, Ferrario A, Schmidt Ml. Epidemiology, management, complications and costs associated with type 2 diabetes in Brazil: a comprehensive literature review. Global Health. 2013;9:62

10. de Almeida-Pititto B, Dias ML, de Moraes AC, Ferreira SR, Franco DR, Eliaschewitz FG. Type 2 diabetes in Brazil: epidemiology and management. Diabetes Metab Syndr Obes. 2015:8:17-28

11. International Diabetes Federation. IDF Diabetes Atlas, 7th edn. Brussels, Belgium: International Diabetes Federation. 2015. http://www.diabetesatlas.org.

12. Ekelund U, Luan J, Sherar LB, Esliger DW, Griew P, Cooper A. Moderate to vigorous physical activity and sedentary time and cardiometabolic risk factors in children and adolescents. JAMA. 2012;307(7):704-12.

13. Fox CS, Coady S, Sorlie PD, D'Agostino RB Sr, Pencina MJ, Vasan RS, Meigs JB, Levy D, Savage PJ. Increasing cardiovascular disease burden due to diabetes mellitus: the Framingham Heart Study. Circulation. 2007:115(12):1544-50.

14. von Elm E, Altman DG, Egger M, Pocock SJ, Gotzsche PC, Vandenbroucke JP, Initiative S. The Strengthening the Reporting of Observational Studies in Epidemiology (STROBE) statement: guidelines for reporting observational studies. Epidemiology. 2007;18(6):800-4
15. Liberati A, Altman DG, Tetzlaff J, Mulrow C, Gotzsche PC, loannidis JP, Clarke M, Devereaux PJ, Kleijnen J, Moher D. The PRISMA statement for reporting systematic reviews and meta-analyses of studies that evaluate healthcare interventions: explanation and elaboration. BMJ. 2009:339:b2700

16. Moher D, Shamseer L, Clarke M, Ghersi D, Liberati A, Petticrew M, Shekelle P, Stewart LA, Group P-P. Preferred reporting items for systematic review and meta-analysis protocols (PRISMA-P) 2015 statement. Syst Rev. 2015;4:1.

17. Almeida AAL, Bonfante HLM, Moreira RO, Arbex AK, Souza GS, Maciel LG, Godinho RR, Giannini G. Perfil epidemiológico do diabetes mellitus auto-referido em uma zona urbana de Juiz de Fora, Minas Gerais. Arq Bras Endocrinol Metab. 1999;43(3):199-204.

18. Barbosa JB, Silva AA, Santos AM, Monteiro Junior F, Barbosa MM, Figueiredo Neto JA, Soares Nde J, Nina VJ, Barbosa JN. Prevalence of arterial hypertension and associated factors in adults in Sao Luis, state of Maranhao. Arq Bras Cardiol. 2008;91(4):236-42 (260-236).

19. Borges TT, Rombaldi AJ, Corrêa LQ, Knuth AG, Hallal PC. Prevalência de autorrelato da morbidade e conhecimento sobre diabetes: estudo populacional de uma cidade no sul do Brasil. Revista Brasileira de Cineantropometria e Desempenho Humano. 2012;14(5):562-70.

20. Capilheira MF, Santos IS, Azevedo MR Jr, Reichert FF. Risk factors for chronic non-communicable diseases and the CARMEN initiative: a population-based study in the South of Brazil. Cad Saude Publica. 2008;24(12):2767-74

21. Carvalhaes MABL, Moura EC, Monteiro CA. Prevalência de fatores de risco para doenças crônicas: inquérito populacional mediante entrevistas telefônicas em Botucatu, São Paulo, 2004. Rev Bras Epidemiol. 2008;11(1):14-23.

22. Coeli CM, Faerstein E, Chor D, Lopes CS, Werneck GL. Gender differences in the socioeconomic gradient in self-reported diabetes: does health service access play a role? Diabetes Res Clin Pract. 2009;86(2):134-9.

23. Correia LL, da Silveira DM, e Silva AC, Campos JS, Machado MM, Rocha HA, da Cunha AJ, Lindsay AC. Prevalence and determinants of obesity and overweight among reproductive age women living in the semi-arid region of Brazil. Cien Saude Colet. 2011;16(1):133-45.

24. Costa LC, Thuler LCS. Fatores associados ao risco para doenças não transmissíveis em adultos brasileiros: estudo transversal de base populacional. R Bras Est Pop. 2012;29(1):133-45.

25. da Costa JS, Olinto MT, Assuncao MC, Gigante DP, Macedo S, Menezes AM. Prevalence of diabetes mellitus in Southern Brazil: a populationbased study. Rev Saude Publica. 2006;40(3):542-5.

26. Francisco PM, Barros MB, Segri NJ, Alves MC, Cesar CL, Malta DC. Comparison of estimates for the self-reported chronic conditions among household survey and telephone survey-Campinas (SP), Brazil. Rev Bras Epidemiol. 2011;14(Suppl 1):5-15.

27. Freitas LRSD, Garcia LP. Evolução da prevalência do diabetes e deste associado à hipertensão arterial no Brasil: análise da Pesquisa Nacional por Amostra de Domicílios, 1998, 2003 e 2008. Epidemiologia e Serviços de Saúde. 2012:21:7-19.

28. Fuchs SC, Moreira LB, Camey SA, Moreira MB, Fuchs FD. Clustering of risk factors for cardiovascular disease among women in Southern Brazil: a population-based study. Cad Saude Publica. 2008;24(Suppl 2):S285-93.

29. Gigante DP, Barros FC, Post CL, Olinto MT. Prevalence and risk factors of obesity in adults. Rev Saude Publica. 1997;31(3):236-46.

30. Iser BPM, Stopa SR, Chueiri PS, Szwarcwald CL, Malta DC, Monteiro HODC, Duncan BB, Schmidt MI. Prevalência de diabetes autorreferido no Brasil: resultados da Pesquisa Nacional de Saúde 2013. Epidemiologia e Serviços de Saúde. 2015;24:305-14.

31. Longo GZ, Neves JD, Castro TGD, Pedroso MRDO, Matos IB. Prevalência e distribuição dos fatores de risco para doenças crônicas não transmissíveis entre adultos da cidade de Lages (SC), sul do Brasil, 2007. Revista Brasileira de Epidemiologia. 2011;14:698-708.

32. Machado VDS, Valadares ALR, da Costa-Paiva LS, Moraes SS, Pinto-Neto AM. Multimorbidity and associated factors in Brazilian women aged 40 to 65 years: a population-based study. Menopause. 2012;19(5):569-75.

33. Machado VDS, Valadares ALR, Costa-Paiva LH, Osis MJ, Sousa MH, PintoNeto AM. Aging, obesity, and multimorbidity in women 50 years or older: a population-based study. Menopause. 2013;20(8):818-24.

34. Monteiro CA, de Moura EC, Jaime PC, Lucca A, Florindo AA, Figueiredo IC, Bernal R, da Silva NN. Surveillance of risk factors for chronic diseases through telephone interviews. Rev Saude Publica. 2005;39(1):47-57. 
35. Moreira LB, Fuchs SC, Wiehe M, Neyeloff JL, Picon RV, Moreira MB, Gus M, Fuchs FD. Cardiovascular risk attributable to diabetes in southern Brazil: a population-based cohort study. Diabetes Care. 2009;32(5):854-6.

36. Munhoz TN, Santos IS, Matijasevich A. Major depressive episode among Brazilian adults: a cross-sectional population-based study. J Affect Disord. 2013;150(2):401-7.

37. Peixoto MDRG, Monego ET, Alexandre VP, Souza RGMD, Moura ECD. Monitoramento por entrevistas telefônicas de fatores de risco para doenças crônicas: experiência de Goiânia, Goiás, Brasil. Cadernos de Saúde Pública. 2008;24:1323-33.

38. Pinheiro MD, Ciconelli RM, Martini LA, Ferraz MB. Risk factors for recurrent falls among Brazilian women and men: the Brazilian Osteoporosis Study (BRAZOS). Cadernos de Saúde Pública. 2010;26(1):89-96.

39. Schellini SA, Carvalho GM, Rendeiro FS, Padovani CR, Hirai FE. Prevalence of diabetes and diabetic retinopathy in a Brazilian population. Ophthalmic Epidemiol. 2014;21(1):33-8.

40. Schmidt MI, Duncan BB, Hoffmann JF, Moura L, Malta DC, Carvalho RM. Prevalence of diabetes and hypertension based on self-reported morbidity survey, Brazil, 2006. Rev Saude Publica. 2009;43(Suppl 2):74-82.

41. Theme-Filha MM, Szwarcwald CL, Souza-Junior PR. Socio-demographic characteristics, treatment coverage, and self-rated health of individuals who reported six chronic diseases in Brazil, 2003. Cad Saude Publica. 2005;21(Suppl):43-53

42. Vianna CA, da Silva Linhares R, Bielemann RM, Machado EC, GonzalezChica DA, Matijasevich AM, Gigante DP, da Silva Dos Santos I. Accuracy and adequacy of waist circumference cut-off points currently recommended in Brazilian adults. Public Health Nutr. 2014;17(4):861-9.

43. Vigitel Brasil 2007. Vigilância de Fatores de Risco e Proteção para Doenças Crônicas por Inquérito Telefônico. Ministério da Saúde, Secretaria de Vigilância em Saúde - Brasília: Ministério da Saúde. 2008.

44. Vigitel Brasil 2008. Vigilância de Fatores de Risco e Proteção para Doenças Crônicas por Inquérito Telefônico. Ministério da Saúde, Secretaria de Vigilância em Saúde - Brasília: Ministério da Saúde. 2009.

45. Vigitel Brasil 2009. Vigilância de Fatores de Risco e Proteção para Doenças Crônicas por Inquérito Telefônico. Ministério da Saúde, Secretaria de Vigilância em Saúde - Brasília: Ministério da Saúde. 2010.

46. Vigitel Brasil 2010. Vigilância de Fatores de Risco e Proteção para Doenças Crônicas por Inquérito Telefônico. Ministério da Saúde, Secretaria de Vigilância em Saúde - Brasília: Ministério da Saúde. 2011.

47. Vigitel Brasil 2011. Vigilância de Fatores de Risco e Proteção para Doenças Crônicas por Inquérito Telefônico. Ministério da Saúde, Secretaria de Vigilância em Saúde - Brasília: Ministério da Saúde. 2012.

48. Vigitel Brasil 2012. Vigilância de Fatores de Risco e Proteção para Doenças Crônicas por Inquérito Telefônico. Ministério da Saúde, Secretaria de Vigilância em Saúde - Brasília: Ministério da Saúde. 2013.

49. Vigitel Brasil 2013. Vigilância de Fatores de Risco e Proteção para Doenças Crônicas por Inquérito Telefônico. Ministério da Saúde, Secretaria de Vigilância em Saúde - Brasília: Ministério da Saúde. 2014.

50. Vigitel Brasil 2014. Vigilância de Fatores de Risco e Proteção para Doenças Crônicas por Inquérito Telefônico. Ministério da Saúde, Secretaria de Vigilância em Saúde - Brasília: Ministério da Saúde. 2015.

51. Cipullo JP, Martin JF, Ciorlia LA, Godoy MR, Cacao JC, Loureiro AA, Cesarino CB, Carvalho AC, Cordeiro JA, Burdmann EDEA. Hypertension prevalence and risk factors in a Brazilian urban population. Arq Bras Cardiol. 2010:94(4):519-26.

52. Makdisse M, Pereira ADC, Brasil DDP, Borges JL, Machado-Coelho GL, Krieger JE, Nascimento Neto RM, Chagas AC. Prevalence and risk factors associated with peripheral arterial disease in the Hearts of Brazil Project. Arq Bras Cardiol. 2008;91(6):370-82.

53. Nunes Filho JR, Debastiani D, Nunes AD, Peres KG. Prevalência de Fatores de risco cardiovascular em adultos de Luzerna, Santa Catarina, 2006. Arquivos Brasileiros de Cardiologia. 2007:89:319-24.

54. Passos VMDA, Barreto SM, Diniz LM, Lima-Costa MF. Type 2 diabetes: prevalence and associated factors in a Brazilian community - the Bambuí health and aging study. Sao Paulo Med J. 2005;123:66-71.

55. Rodrigues SL, Baldo MP, Capingana P, Magalhaes P, Dantas EM, Molina MDC, Salaroli LB, Morelato RL, Mill JG. Gender distribution of serum uric acid and cardiovascular risk factors: population based study. Arq Bras Cardiol. 2012;98(1):13-21.
56. Schaan BD, Harzheim E, Gus I. Cardiac risk profile in diabetes mellitus and impaired fasting glucose. Rev Saude Publica. 2004;38(4):529-36.

57. Souza LJD, Chalita FEB, Reis AFF, Teixeira CL, Gicovate Neto C, Bastos DA, Filho JTDS, Souza TFD, Côrtes VA. Prevalência de diabetes mellitus e fatores de risco em Campos dos Goytacazes, RJ. Arq Bras Endocrinol Metabol. 2003;47:69-74

58. Bosi PL, Carvalho AM, Contrera D, Casale G, Pereira MA, Gronner MF, Diogo TM, Torquarto MT, Oishi J, Leal AM. Prevalence of diabetes and impaired glucose tolerance in the urban population of 30 to 79 years of the city of Sao Carlos, Sao Paulo. Arq Bras Endocrinol Metabol. 2009;53(6):726-32

59. Malerbi DA, Franco LJ. Multicenter study of the prevalence of diabetes mellitus and impaired glucose tolerance in the urban Brazilian population aged 30-69 years. The Brazilian Cooperative Group on the Study of Diabetes Prevalence. Diabetes Care. 1992;15(11):1509-16.

60. Moraes SA, Freitas IC, Gimeno SG, Mondini L. Diabetes mellitus prevalence and associated factors in adults in Ribeirao Preto, Sao Paulo, Brazil, 2006: OBEDIARP Project. Cad Saude Publica. 2010;26(5):929-41.

61. Oliveira JE, Milech A, Franco LJ. The prevalence of diabetes in Rio de Janeiro, Brazil. The Cooperative Group for the Study of Diabetes Prevalence in Rio De Janeiro. Diabetes Care. 1996;19(6):663-6.

62. Rodrigues Junior W, Gaban SC, Pontes ER, Souza CC, Gimenes LP, Lacerda PF, Cunha ML, Stefanello IJ, Brum LM, Oliveira LA, et al. Diabetes mellitus and impaired glucose tolerance in urban adult population. Rev Assoc Med Bras. 2014;60(2):118-24.

63. Schmidt MI, Hoffmann JF, de Fatima Sander Diniz M, Lotufo PA, Griep RH, Bensenor IM, Mill JG, Barreto SM, Aquino EM, Duncan BB. High prevalence of diabetes and intermediate hyperglycemia-The Brazilian Longitudinal Study of Adult Health (ELSA-Brasil). Diabetol Metab Syndr. 2014;6:123

64. Torquato MT, Montenegro Junior RM, Viana LA, de Souza RA, Lanna CM, Lucas JC, Bidurin C, Foss MC. Prevalence of diabetes mellitus and impaired glucose tolerance in the urban population aged 30-69 years in Ribeirao Preto (Sao Paulo), Brazil. Sao Paulo Med J. 2003;121(6):224-30.

65. Herman WH, Zimmet P. Type 2 diabetes: an epidemic requiring global attention and urgent action. Diabetes Care. 2012;35(5):943-4

66. Shaw JE, Sicree RA, Zimmet PZ. Global estimates of the prevalence of diabetes for 2010 and 2030. Diabetes Res Clin Pract. 2010;87(1):4-14.

67. Dourado I, Oliveira VB, Aquino R, Bonolo P, Lima-Costa MF, Medina MG,

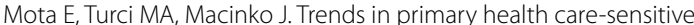
conditions in Brazil: the role of the Family Health Program (Project ICSAPBrazil). Med Care. 2011:49(6):577-84

68. Standards of medical care in diabetes - 2015: summary of revisions. Diabetes Care. 2015;38 Suppl:S4

69. Collaboration NCDRF. Effects of diabetes definition on global surveillance of diabetes prevalence and diagnosis: a pooled analysis of 96 populationbased studies with 331,288 participants. Lancet Diabetes Endocrinol. 2015;3(8):624-37.

70. Colditz GA, Willett WC, Rotnitzky A, Manson JE. Weight gain as a risk factor for clinical diabetes mellitus in women. Ann Intern Med. 1995:122(7):481-6.

71. Willett WC, Dietz WH, Colditz GA. Guidelines for healthy weight. N Engl J Med. 1999:341(6):427-34

72. Cheng YJ, Imperatore G, Geiss LS, Wang J, Saydah SH, Cowie CC, Gregg EW. Secular changes in the age-specific prevalence of diabetes among US adults: 1988-2010. Diabetes Care. 2013;36(9):2690-6.

73. Nichols GA, Schroeder EB, Karter AJ, Gregg EW, Desai J, Lawrence JM, O'Connor PJ, Xu S, Newton KM, Raebel MA, et al. Trends in diabetes incidence among 7 million insured adults, 2006-2011 the SUPREME-DM project. Am J Epidemiol. 2015;181(1):32-9.

74. Gregg EW, Li Y, Wang J, Burrows NR, Ali MK, Rolka D, Williams DE, Geiss L. Changes in diabetes-related complications in the United States, 1990-2010. N Engl J Med. 2014;370(16):1514-23.

75. Tschiedel B, Ce GV, Geremia C, Mondadori P, Speggiorin S, Punales MK. Establishment of a collaborative work team management for type 1 diabetes mellitus patient. Arquivos brasileiros de endocrinologia e metabologia. 2008;52(2):219-32.

76. BRASIL. Ministério da Saúde: Plano de Reorganização Da Atenção à Hipertensão Arterial E Ao Diabetes Mellitus. Brasília. 2002. 
77. Hilawe EH, Yatsuya H, Kawaguchi L, Aoyama A. Differences by sex in the prevalence of diabetes mellitus, impaired fasting glycaemia and impaired glucose tolerance in sub-Saharan Africa: a systematic review and metaanalysis. Bull World Health Organ. 2013;91(9):671-682D.
78. Cleland VJ, Schmidt MD, Dwyer T, Venn AJ. Television viewing and abdominal obesity in young adults: is the association mediated by food and beverage consumption during viewing time or reduced leisure-time physical activity? Am J Clin Nutr. 2008;87(5):1148-55.

\section{Submit your next manuscript to BioMed Central and we will help you at every step:}

- We accept pre-submission inquiries

- Our selector tool helps you to find the most relevant journal

- We provide round the clock customer support

- Convenient online submission

- Thorough peer review

- Inclusion in PubMed and all major indexing services

- Maximum visibility for your research

Submit your manuscript at

www.biomedcentral com/submit 